\title{
Ornamental Plants Help to Beautify your Surrounding and Liberate Oxygen
}

ISSN: 2637-7659

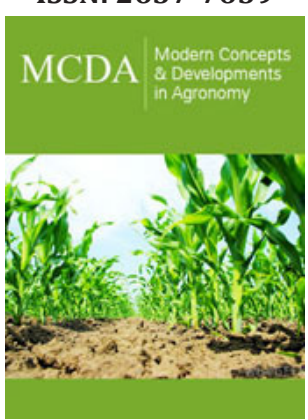

*Corresponding author: Manju Das, Department of Oceanography, TIU, Salt Lake, Kolkata-95, India

Submission: 紫June 08, 2019

Published: 㘹August 04, 2020

Volume 7 - Issue 1

How to cite this article: Manju Das, Biswas SK, Zaman S, Mitra A. Ornamental Plants Help to Beautify your Surrounding and Liberate Oxygen. Mod Concep Dev Agrono. 7(1). MCDA. 000651. 2020. DOI: 10.31031/MCDA.2020.07.000651

Copyright@ Manju Das, This article is distributed under the terms of the Creative Commons Attribution 4.0 International License, which permits unrestricted use and redistribution provided that the original author and source are credited.

\author{
Manju Das ${ }^{1}$, Biswas $\mathrm{SK}^{2}$, Zaman $\mathrm{S}^{1}$, and Mitra $\mathrm{A}^{3}$ \\ ${ }^{1}$ Department of Oceanography, TIU, Salt Lake, Kolkata-95, India \\ ${ }^{2}$ Department of Civil Engineering, TIU, Salt Lake, India \\ ${ }^{3}$ Department of Marine Science. C.U. Kolkata, West Bengal, India
}

\begin{abstract}
Utility of keeping ornamental plants not only beautify your place of residence but helps to add oxygen to purify air. Plants absorb more carbon-di-oxide during daytime and prepare their own food. Oxygen releases to the surroundings and helps to breathe properly. Dates back from Mesopotamian era human settlement has a tendency to beautify their surroundings with ornamental plants. ("First use of ornamental plants in the history of urbanization" by Osman Zeybek [1]). Different chrome in leaves are quite attractive. It attracts human eyes too. Keeping ornamental plants and decorate is a natural tendency of human habitation.
\end{abstract}

Keywords: Ornamental plants; Oxygen; Chrome; Human habitation

\section{Introduction}

Ornamental plants in small pots or in soil of adjacent house is quite remarkable. Growth of those plants depend upon care. Water, Sunlight, sufficient air, and temperature record is necessary at least for twice a day. In the morning and before evening plants require water and need care to watch their growth day by day. Size of leaf, length of stem, colour of leaves, roots are in soil. This wonderful heart shaped Arum sp. is monocotyledonous. It propagates through bulbs. Roots are wonderful to preserve for anatomical and physiological structures. Internal arrangement of cells is like monocot plants.

\section{Materials and Method}

Few bulbs with stem and leaves are embedded in soil placed in ornamental earthen pot. Mainly alluvial soil is suitable to grow this plant. Number of stems and number of leaves are increasing (Figure 1\&2). During monsoon leaves are more attractive with bright red and green coloured foliage. Leaf lamina is heart shaped. Sometimes in outer margin of leaf lamina water droplets appear due to transpiration. Watching development and growth of plants is interesting (Table 1). Watering is an important part for this ornamental plant. Painting of this ornamental plant's pot will add more attraction.

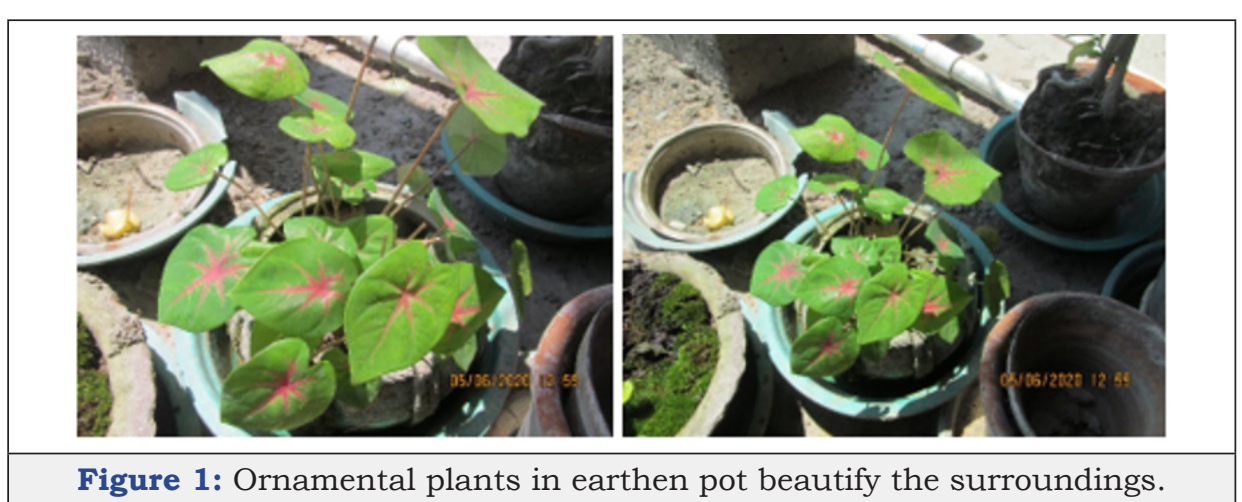




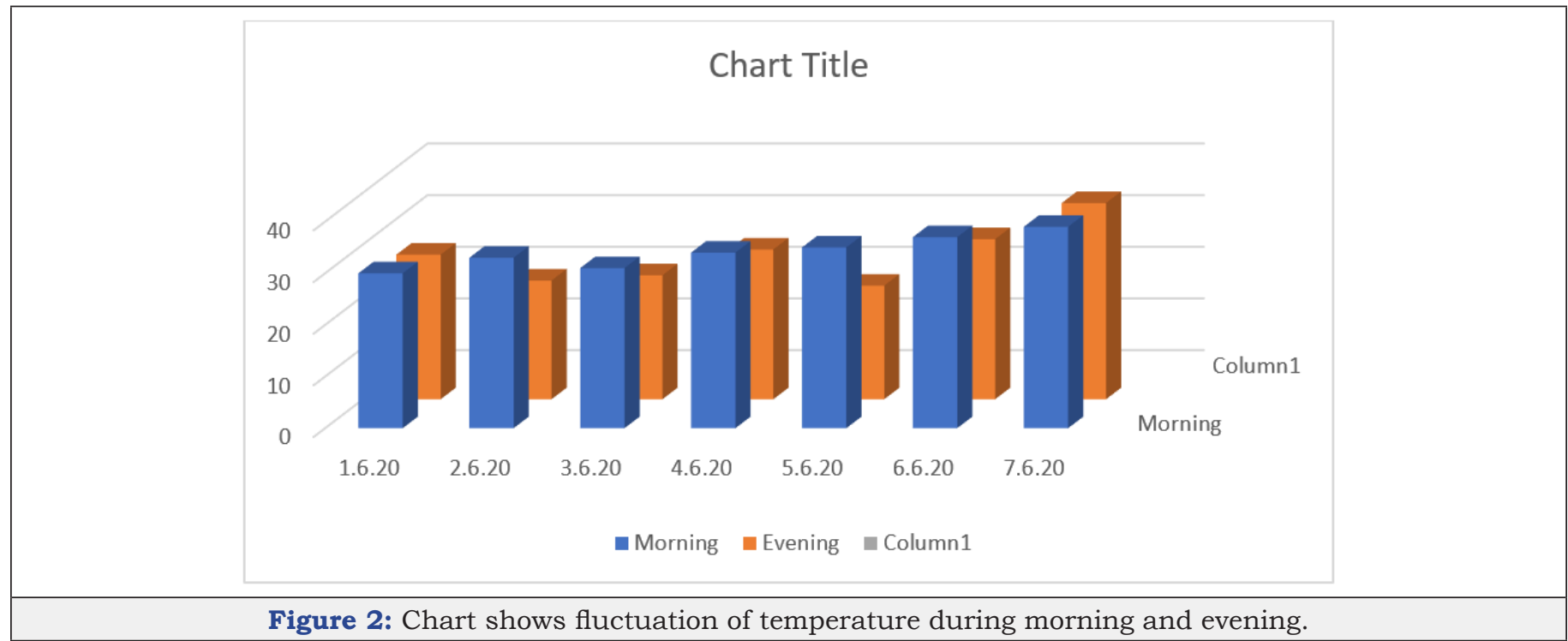

Table 1: Table records seven days temperature of surrounding environment.

\begin{tabular}{|c|c|c|}
\hline Date & Morning & Evening \\
\hline 1.6 .20 & $30^{\circ} \mathrm{C}$ & $28^{\circ} \mathrm{C}$ \\
\hline 2.6 .20 & $33^{\circ} \mathrm{C}$ & $23^{\circ} \mathrm{C}$ \\
\hline 3.6 .20 & $31^{\circ} \mathrm{C}$ & $24^{\circ} \mathrm{C}$ \\
\hline 4.6 .20 & $34^{\circ} \mathrm{C}$ & $29^{\circ} \mathrm{C}$ \\
\hline 5.6 .20 & $35^{\circ} \mathrm{C}$ & $22^{\circ} \mathrm{C}$ \\
\hline 6.6 .20 & $37^{\circ} \mathrm{C}$ & $31^{\circ} \mathrm{C}$ \\
\hline 7.6 .20 & $39^{\circ} \mathrm{C}$ & $38^{\circ} \mathrm{C}$ \\
\hline
\end{tabular}

Result

Ornamental plants are maintained in Park, garden, office, educational institute in road partition as well as in home décor.
Keeping plants with wide spaces helps to propagate those Arum $s p$. Externally they are healthy with more foliage day by day and scarcity of water may destroy those plants.

\section{Conclusion}

Maintaing plants will purify air. Beautification is another profit.

\section{References}

1. Zeybek O (2019) First use of ornamental plants in the history of urbanization. 